\title{
Metaphors of Life in Bhagavad Gita As It Is
}

\author{
Ni LuhPutuSisiana Dewi \\ English Department, Faculty of Arts, Udayana University \\ ${ }^{1}$ [sisianadewi@gmail.com]
}

\begin{abstract}
Metaphors are frequently used in everyday conversation unconsciously. People deliver the metaphoric expressions underlaid by conceptual metaphor that consists of the target and source domains. This study aims to find out the types of metaphorical expressions and analyze the conceptual metaphors underlaying the metaphorical expressions. The data were generated from Bhagavad Gita text using a corpus machine named AntConc 3.4.4w. With the corpus method and AntConc, 690 sentences containing metaphors of life were found. These data were analyzed by applying the conceptual metaphor theory of Lakoff and Johnson (2003) and Steen (2007).The result of the study shows that the metaphorical expressions of life in Bhagavad Gita are covered in all types of metaphor, they are: Structural, Ontological (along with its subsection that is Personification), and Orientational metaphors. In Bhagavad Gita, there are 24 conceptual metaphors that underlay the metaphorical expressions. The most frequently found conceptual metaphors were LIFE IS AN ENTITY, LIFE IS A JOURNEY and LIFE IS A CONTINUOUS ACTIVITY.
\end{abstract}

Keyword: life, metaphorical expressions, conceptual metaphor, source domain and target domain.

\begin{abstract}
Abstrak
Metafora sering digunakan dalam percakapan sehari-hari tanpa disadari. Orang-orang menyampaikan ungkapan metaforis dengan dilatarbelakangi oleh metafora konseptual yang terdiri dari ranah target dan ranah sumber. Penelitian ini bertujuan untuk mengidentifikasi tipe ungkapan metaforis dan menganalisis metafora konseptual yang melatarbelakangi ungkapan-ungkapan tersebut. Data penelitian ini dikumpulkan dari teks Bhagavad Gita menggunakan mesin penjelajah bernama AntConc versi 3.4.4w. Dengan metode corpus dan mesin AntConc tersebut dapat ditemukan 690 kalimat yang mengandung metafora kehidupan. Data tersebut dianalisis dengan teori metafora konseptual yang dipelopori oleh Lakoff dan Johnson (2003) serta Steen (2007). Hasil analisis menunjukkan bahwa ungkapan metaforis tentang kehidupan pada Bhagavad Gita tercakup dalam semua jenis metafora termasuk tipe Struktural, Ontologis (beserta sub bagiannya yaitu Personifikasi), dan Orientasional. Dalam Bhagavad Gita, terdapat 24 metafora konseptual yang mendasari ungkapan metaforis. Metafora konseptual yang paling sering ditemukan ialah KEHIDUPAN ADALAH ENTITAS, KEHIDUPAN ADALAH PERJALANAN, dan KEHIDUPAN ADALAH AKTIVITAS YANG BERKELANJUTAN.
\end{abstract}

Kata kunci: kehidupan, ungkapan metaforis, metafora konseptual, ranah sumber, dan 


\section{Background}

ranah target.

As a major study within semantics, metaphors take a great role in everyday life. People unconsciously speak metaphorically in their daily conversations.

Lakoff \& Johnson (2003) and Kövecses (2010) proposed a new perspective on metaphor.It is not solely based on similarities. It is a property of concept and not only used in some artistic or rhetoric purposes. Metaphor is also used by ordinary people, not only a poet, because human thought processes are largely metaphorical. This is what it means when the new view of metaphor is based on human conceptual system which is metaphorically structured and defined. Rajeg (2016) also stated that the concept of target domain is structured in our conceptual system and is expressed through our language.

Metaphorical expressions are the expression of metaphor or linguistic metaphors which are produced by human thought processes in metaphorical concept. This metaphorical expression has three types which can be classified into: orientational metaphor, structural metaphor, and ontological metaphor. Each type has different kind and function towards metaphorical concept. As stated by Kövecses (2010: 40), orientational metaphor derives from the fact that most metaphors that serve this function have to do with basic human spatial orientations, such as up-down, center-periphery, and the like. HAPPY IS UP and SAD IS DOWN are the conceptual metaphors classified into orientational metaphor.

Conceptual metaphor is a structure between the target domain and the source domain. Target domain is the abstract element that needs the source domain to help understand the target domain. As an example, a conceptual metaphor is LIFE IS A JOURNEY. This metaphorical concept constructs two domains which function to understand one conceptual domain to other conceptual domain. The target domain in this metaphorical concept is life, and the source domain is journey. From this concept, the expression is constructed based on this metaphorical concept. The metaphorical expression can be seen, for instance, in the following sentence: In the middle of the road of life, I found myself lost. This metaphorical expression is constructed based on the conceptual metaphor LIFE IS A JOURNEY. It can be seen from the target domain life and the source domain road. The road in this context representsLIFE IS A JOURNEY, because road is analogous with the journey. The next phrase also strengthens the proof of the conceptual metaphor, because people can lose a direction when they are going through a journey which is related to the road.

This study is investigating the word 'life' in Bhagavad Gita As It Is. Life is related to something that people do in this world before they die. There are many metaphorical expressions used to express life. One of the metaphorical expressions in Bhagavad Gita is: Life is a preparation for the next life. It will be classified into the types of metaphorical expressions and the Steen's Five Procedure of identifying metaphors is applied to find its conceptual metaphor that underlay the expression.

\section{Problems of the Study}

a) What types of metaphorical expressions oflife are found in Bhagavad Gita As It Is? 
b) What conceptual metaphors underlay the metaphorical expressions of life in Bhagavad Gita As It Is?

\section{Aims of the Study}

a) To identify and classify the types of metaphorical expression of life found in Bhagavad Gita As It Is

b) To analyze and describe the conceptual metaphor underlaying the metaphorical expressions in Bhagavad Gita As It Is

\section{Research Method}

A combination of qualitative and quantitative methods is applied in this study. The qualitative method is applied to describe the types of metaphors and the qualitative one is used as a supporting method, especially in the quantification of the occurrence of the linguistic expressions the concordance. This section has four points of discussion. They are data source, method and technique of collecting data, method and technique of analyzing data, and method and technique of presenting analyzed data.

\subsection{Data Source}

The source of data of this study is a well-known Vedic literature. It is widely known as Bhagavad Gita. It is the Song of the Lords, often referred to as simply the Gita, a 700-verse Hindu scripture in Sanskrit that is part of the Hindu epic of Mahabharata (chapters 23-40 of the 6th book of Mahabharata). It reflects the philosophy of life that has been analyzed by The Theosophical Society in America in 2000. Many other discussions and analysis are conducted related to it. Bhagavad Gita as the song of the Lords contains an explanation to describe a life. It contains the dialogues when Krishna gave Arjuna some advices before going to the battlefield. The advices which were given by Krishna are containing the advices of life. Therefore, Bhagavad Gita is a suitable data source to explore the target domain of life.

\subsection{Method and Technique of Collecting Data}

In collecting the data of this study, the documentation method is appliedsupported by a note-taking technique. The research was done in the library as well as in the computer laboratoium. The first thing to do was to download the electronic pdf files of the Bhagavad Gita. The files were, then, converted into plain texts (txt) Files.The conversion is necessary for the AntConc, corpus machine, to read them to generate a concordance. By using a keyword life, a concordance was generated from which the data were identified and note-taken for further analysis.

\subsection{Method and Technique of Analyzing Data}

This research applied descriptive method supported with qualitative and quantitative technique to analyze the data. The identified data were classified based on the types of metaphorical expressions. The occurances of each type were quantified to see the frequency of the use of the metaphorical expressions. The frequency was used to determine the conceptual metaphors that motivate the use of the metaphorical expressions.

\subsection{Method and Technique of Presenting Data}

The data are presented in informal method which is presented descriptively. It is formulated with a procedure to comprehend the conceptual metaphor, and 
then it is classified into the types of metaphorical expression. Certain types of metaphorical expressions are given some explanation and further analysis. There are also steps in mapping the linguistic metaphor into conceptual metaphor.

\section{Result and Discussion}

There are 690 data which contain the word 'life' in Bhagavad Gita. It was found that there were some conceptual metaphors that describe life as something that can be explained through the source domain. The target domain 'life' in Bhagavad Gita refers to LIFE IS AN ENTITY which means that a life is an existencesomething that already exists. It was also found that the results of conceptual metaphor in Bhagavad Gita are LIFE IS A JOURNEY and LIFE IS A CONTINUOUS ACTIVITY. Furthermore, the expression is provided with bold letters in focus to the source domain, and the italic letters is focusing to the target domain. The conceptual metaphor is described with bold and capital letters.

The metaphorical expressions in Bhagavad Gita are coveredin three types, i.e. structural metaphor, orientational metaphor, ontological metaphor, and personification (as the extension of ontological metaphor). However, in this part, the most meaningful conceptual metaphor related to daily life is explained and discussed.

\section{LIFE IS A STRUGGLE}

Expression: ...may call you bad names but that you will save your life by fleeing the battlefield...

Step 1:

Life
Step 2:

P1 (save your life)

P2 (will P1)

P3 (Mod P2by)

Step 3:

SIM

$$
\begin{aligned}
& \{\exists F \text { ヨ } a \\
& {[\mathrm{F}(\text { life })] \mathrm{t}} \\
& [\text { save }(a)] \mathrm{s}\}
\end{aligned}
$$

Step 4:

SIM

$\{[$ to make it possible for someone or something to avoid danger, harm, injury (life)]t $[($ struggle $)] \mathrm{s}\}$

Step 5:

\section{LIFE $>$ STRUGGLE}

\section{Inferences: LIFE IS A STRUGGLE}

Life is full of so many challenges, even in Bhagavad Gita there are 22 metaphorical expressions containing the conceptual metaphor of LIFE IS A STRUGGLE. The metaphorical expression shows that save as the source domain. In lexical meaning from MacMillan Dictionary, it means to make it possible for someone or something to avoid danger, harm, and injury. Based on this meaning we already understand what a life is. Life is an action to keep ourselves safe and comfort by avoiding danger or harm. The action of avoiding danger is a struggle. Based on its lexical meaning, struggle is to try hard to do something that seems very difficult. Saving a life from danger seems very difficult which related to the source domain of conceptual metaphor 'struggle' 
The struggle already happened before we were born and still continue when we still breathing. There will always be something that we struggled for. Every creature is breathing to make their life last longer. They breathe to survive, and they breathe to prolong their life. The source domain save shows its relation to conceptual metaphor of LIFE IS A STRUGGLE, because saving a life is a strategy in survival, a survival indicates a challenging task in life which means to make life last longer is a struggle. Life will always have a struggle; there will always be a struggle.

\section{Conclusions}

It can be concluded that the metaphorical expressions of life in Bhagavad Gita covered all of the types, that is structural, ontological, orientational, as well as its related figure, personification. There are 690 sentences related to life found in Bhagavad Gita. Out of this number, 394 are metaphorical expressions and 296 literal expressions. A total of 24 conceptual metaphorsare found in Bhagavad Gita with 6 conceptual metaphors belong to structural type, 15 conceptual metaphors ontological type, 2 conceptual metaphorsorientational type, and 1 conceptual metaphor of personification type.

Based on the quantitative analysis, it was indicated that in Bhagavad Gita, life is more often expressed metaphorically rather than literally. It was found that life $42.9 \%$ talked about literary and $57.1 \%$ was expressed metaphorically. It can be said that life in Bhagavad Gita is predominantly expressed using metaphors.

The conceptual metaphors motivating the use of metaphorical expressionsordered by the number of frequency of occurrences are LIFE IS AN ENTITY (65); LIFE IS A JOURNEY (57), LIFE IS A CONTINUOUS ACTIVITY (55)LIFE IS A MOVABLE OBJECT (orientational: 23, ontological: 18) LIFE IS A CONTAINER (orientational: 35, ontological: 5) LIFE IS A PROBLEM (26) LIFE IS A STRUGGLE (22)LIFE IS A LIVING BEING (19)LIFE IS AN ARRANGEABLE OBJECT (12) LIFE IS A DRINK (11) LIFE IS A SOCIETY (11) LIFE IS A GIFT (5) LIFE IS AN ART (4) LIFE IS A BREATH (4) LIFE IS A CREATION (4)LIFE IS A VALUABLE THING (4) LIFE IS A HUMAN(3) LIFE IS AN EQUIPMENT (3) LIFE IS A HIERARCHY (3) LIFE IS A WORTHLESS THING (2) LIFE IS A PLANT (2) LIFE IS A SPACE (1)

Based on the data, it can be concluded that the most frequently used metaphorical expressions related to life isLIFE IS AN ENTITY. It was found that LIFE IS AN ENTITY, LIFE IS A JOURNEY, and LIFE IS A CONTINUOUS ACTIVITY are the most frequent conceptual metaphors in Bhagavad Gita.

\section{References}

Anthony, Laurence (2014). AntConc (Version 3.4.4w) [Windows Corpus Application] Available from: URL http://www.laurenceanthony.net/sof tware/AntConc/

Bhakti Vedanta Svami Prabupada (1998).Bhagavad Gita As It Is. Los Angeles: Bhaktivedanta Book Trust International.

Kövecses, Zoltan (2010). Metaphor A Practical Introduction. New York: Oxford University Press. 
Lakoff, George and Johnson, Mark (2003).

Metaphors we live by. London: The university of Chicago press.

Rajeg, I Made (2016). Metaphoric and Metonymic Conceptualization of Love in Indonesian. International Journal of Linguistics, Language and Culture (IJLLC): Vol. 2, No. 3, September 2016; pp. 71 83

ISSN: $2455-8028$

Steen, Gerard (2007). Finding Metaphor in Discourse: Pragglejaz and Beyond. Vol. 5. ISSN 1697-7750, pp 9-25. 